\title{
THE LEGAL PROTECTION OF CONSUMERS FOR ACQUISITION PDAM CLEAN WATER SERVICE (The Case Study Of PDAM Surabaya City)
}

\author{
${ }^{1}$ Rista Veria Dewi, ${ }^{2}$ Djulaeka \\ 1,2 Universitas Trunojoyo Madura, Bangkalan, Indonesia \\ email: ${ }^{1 *}$ ristaveria13@gmail.com, ${ }^{2}$ djulaeka@trunojoyo.ac.id
}

\begin{abstract}
This study was conducted to determine the existence of negligence on the quality standard of water that is flowed by PDAM Surya Sembada, as well as legal remedies that can be carried out by consumers who suffer losses from the clean water services they receive. The research method used is normative research. The research approach is was carried out using a legislative aprroarch, namely by reviewing the law in accordance with legal issues raised related to water quality standards and the responsibilities of PDAM Surya Sembada as the service provider of clean water service recipients in the Surya Sembada City PDAM Surabaya as a cunsumers. The results showed that the service recipient felt disadvantaged, because there were several aspects of the quality standard of water that was flowed as reflected in the provisions of Permenkes No. 492 of 2010 concerning Requirements for Drinking Water Quality that were not appropriate and the provision of compensation by clean water service providers to the recipients of services whose right have been impaired is also not carried out properly, so that consumers as service recipients can file claims related to compensation suffered through out of court (no litigation) and court (litigation) ways.
\end{abstract}

Keywords: PDAM Surya Sembada; water quality standards; consumer legal measures

\section{Introduction}

Based on mandate of 1945 Constitution of the Republic Indonesia, the Regional Government has the authority to regulate and manage government affairs by itself according to the principle of autonomy. Regional autonomy is the right, authority and obligation of the autonomous region to regulate and manage government affairs and the interests of local communities in NKRI system. The implementation of regional government is directed at accelerating the realization of community welfare through improving services, empowerment and community 
participation, as well as increasing regional competitiveness by taking into account the principles of democracy, equity, justice and the uniqueness of a region in NKRI system.

Indonesia is classified as a country that is rich in abundant natural resources. It is stated in provisions of Article 33 paragraph (3) of 1945 Indonesian Constitution which reads "The land, water and natural resources contained therein are controlled by the State and used for the greatest possible welfare of the people". The state also guarantees the right of everyone to get water as a basic daily need to fulfill a healthy, clean and productive life. It has been regulated in the provisions of Article 5 of Law Number 17 of 2019 concerning Water Resources (hereinafter referred to SDA Law).

Water is one of the natural resources which has a very important function for human life, and it can promote general welfare, so it is the basic capital and the main factor for development. Water is one of the most important needs and it is needed by the all living things, especially humans. Human daily life cannot be separated from their needs, especially water. It is normal for supplying of clean water to take priority in its fulfillment. as the times evolved, the community growth is also increasing, which is also accompanied by economic growth and industrial development which causes the necessity for water to increase so that it is necessary to have water resources management that obligate while still paying attention to the existing of socioeconomic functions.

The management of water resources needs to be directed so that the implementation of public services is in accordance with the principles of good government, in addition to realizing the legal certainty in granting the rights and obligations to the related parties. Therefore, a management agency is needed that can provide the raw water to be clean water until it can be distributed to the consumers (read: customers).

Regional Drinking Water Company (hereinafter referred to PDAM) is a regionally owned company engaged in providing clean water services for consumers. PDAM provides clean water services for all communities fairly and equitably. The service in this case is defined as a service that is provided by service providers in the form of attitudes and characteristics in providing a service for customer satisfaction. This public service has a very broad scope, which includes both the profit and nonprofit sectors based on the objectives of an agency or company institution (Sofie, 
2000). Even though it is classified as a profit, a company like PDAM has greatly given benefits to many people. PDAM Surya Sembada which is the object of research is a Regional Owned Enterprise (hereinafter referred to BUMD) in Surabaya city, which is a business entity whose capital is obtained from the region. PDAM was established by the government to provide clean water services where the organizational structure is under of the auspices of local governments. By the existing of PDAM service, it can be a source of income for the region.

PDAM activities include collecting, producing, and purifying up to the distribution stage to consumers. Along with the rapid population growth, the necessity of drinking water continues to increase. It will encourage the people to contact PDAM for those who do not have a source of drinking water. In this case, there is an obligation from the service recipient, those are the consumer to give compensation for the service that they have received according to the amount of water that they consumed and according to the rate that are set to PDAM as the provider of drinking water supply services. Besides that, there are also rights of service recipients or consumers, among others are; the right to safety and safety in consuming clean water that they have received, the right to get correct information, it is also clear and honest about the condition of the water that they consume, the right to be heard about their opinions and complaints related to the services that they have received from PDAM. In this case, PDAM and consumers are bound by a legal relationship that is a relationship that creates the rights and obligations between both parties.

Consumer protection is something that is needed because it is closely related as an effort to make the people prosperous. Concerning about consumer protection has become a global concern, so it is not only in Indonesia. Therefore, the problems that occur relating to consumers are highly prioritized.

Based on the considerations stated in Law Number 8 of 1999 concerning Consumer Protection (hereinafter referred to as UUPK) states that:

1) Whereas national development is aimed to realize the prosperous of society that is evenly distributed materially and spiritually in economic democracy era based on Pancasila and the Constitution of 1945;

2) Whereas the development of national economy in the era of globalization must be able to support the growth of the business world so that it is capable in producing 
various things and services that have technology which can improve the welfare of many people and at the same time obtain certainty for things and / services obtained from trade without causing consumer losses;

3) Whereas the increasing opening of the national market as a result of economic globalization process. It must guarantee the improvement of public welfare as well as certainty over the quality, quantity and safety of things and / or obtained in the market;

4) Whereas in order to increase the dignity of consumers, it is necessary to increase awareness, knowledge, concern, ability and independence of consumers to protect themselves and to develop and develop responsible business behavior attitudes;

5) Whereas the legal provisions protecting the interests of consumers in Indonesia are inadequate;

6) Whereas based on those considerations, it is necessary to have a set of laws and regulations to achieve a balance in protecting the interests of consumers and businessmen (business actor) so that it can create a healthy economy;

7) Whereas it is necessary to establish a law about consumer protection.

Generally, the law of consumer protection aims to provide legal protection for consumers, both private and public law. Based on the provisions in Article 1 Number 1 UUPK states, that consumer protection is "All efforts that ensure legal certainty to provide the legal protection towards consumers." This sentence is expected to be a defense to eliminate arbitrary actions which taken by business actors against consumers only to fulfill personal interests.

It can be understood that consumer protection always discusses about the protection which given to the consumers in their activities to obtain things and services. The consumer protection law can be interpreted as a law that regulates the granting of rights and obligations to consumers, so that the consumers are able to defend what they should be asked to do. Under these circumstances, the government issued UUPK as a form of effort to solve the consumer protection problems.

With the enforcement of the Consumer Protection Law, it is expected that law enforcement and protection measures can be applied equally to consumers and business actors. Thus, this Law is a form of legal umbrella for society to protect their rights or at least consumers already have a stronghold in defending their rights. 
Likewise, business actors in the provision of clean water are expected to always be able to improve the quality of their service products.

In fact, there are still consumers or customers who complain about the services of PDAM Kota Surabaya. To get a clear picture of the problem of public services, especially in the provision of clean water for the benefit of consumers, there is one case that is related to consumer protection, namely the shutdown of PDAM water for several days in the city of Surabaya which resulted in PDAM consumers being prevented from carrying out daily activities.

There are consumers also complain that the water get is murky. The consumers receive a very murky water supply similar to brewed coffee and milk. It is certain that water in this condition is not suitable for use in the toilet exactly to be consumed. Djoen, a resident of Banyu Urip Lor, Sawahan sub-district, Surabaya City, complained about the turbidity of PDAM water. If you put coins in the water, you cannot see the coins because it is too murky. The same thing happened to Lukman, a resident of Ketintang, Surabaya City, that the water obtained by PDAM Surya Sembada which is flowed from the bathroom faucet into a bucket, just like a dark brown puddle. Some of the things experienced are examples of complaints submitted by consumers regarding PDAM Kota Surabaya services. The existence of PDAM Kota Surabaya is expected to accommodate the interests of consumers and to protect their rights according to what has been stated in the UUPK. The evidence from customer complaints that PDAM Surabaya City water is identified as murky, it can be seen from the results of research which shows that the water quality standard in a number of rivers in Surabaya City has reached $100 \mathrm{mg}$ per liter due to contamination by domestic waste. This figure exceeds the Biological Oxygen Demand (BOD) quality standard set by the government, which is 12 milligrams per liter. The expeart of Environmental Technology form IT, he is Agus Slame has researched that, to be able to find out the water quality standard, it was done by taking water samples in several rivers in the city of Surabaya. The research was conducted by making a small simulation of how the river water could be badly polluted. One of the causes of water pollution is 70 until 80 percent of the water that enters the river is not processed. The household wastewater is discharged directly into the channel (drainage), then flows into the river which is then used as raw material for PDAM water. Based on the results of ITS research, it shows that, a person usually spends about 180 liters of clean water 
a day. Generally $80 \%$ of clean water is used for daily needs such as bathing, washing clothes and kitchen needs. Meanwhile, 20\% went to the toilet. About 70 until $80 \%$ of the liquid requirement then becomes liquid waste. Seeing this figure, you can imagine the amount of household liquid waste produced by Surabaya residents is very pitiful. Moreover, all the liquid waste from the residents is discharged into the river. Researchers from ITS have also stated that the liquid waste discharged into the river contains a lot of detergent, soap, and other chemicals. The waste flows into the sea, precisely on the East Coast of Surabaya, if this pollution occurs continuously it can damage the ecosystem (Kumalasari, 2011)

The clean water is the most important need for all people. Getting quality water has become a public demand until now. All community activities always need clean water. The community also understands the importance of clean water for a healthy life. The geographical condition of the city of Surabaya has partly supported the availability of clean water for the surrounding community.

Consumers pay more attention to their interests so that they are not always on the disadvantaged part. PDAM as a producer or provider of things and / or services in the form of water needs has an obligation to provide the best service to consumers in accordance with the production standards required by consumers. PDAM has the right to obtain and receive replacement fees for water services supplied to consumers. In addition, consumers also have the right to obtain and receive compensation for the water services that they have received. The existence of a legal relationship between the PDAM and consumers is proofed by the monthly payment of fees made by consumers to fulfill the clean water supply. Based on the description above, the formulations of the problems in this study are:

1. Is the water quality standard which identified as being murky can be said that PDAM has committed an act of breaking the law?

2. Are the consumers can claims for compensation related to the quality of water in PDAM Surabaya City?

\section{Research Methods}

\section{Types of Research}

The problem approach method used in this paper is a normative legal research method. Normative legal research is also called doctrinal as legal research. 
Normative legal research is often conceptualized in relation to what is written in statutory regulations (law in books) or law is conceptualized as a rule or norm which is a benchmark in human behavior which is deemed appropriate (Amiruddin, 2012) The normative research in this research is manifested in the form of reviewing the legal rules regarding consumer protection for the acquisition of clean water services in PDAM Surabaya City with the regulation of the Consumer Protection Law Number 8 of 1999.

\section{Research Approaches}

The approach that is used is the statutory approach, which is an approach that is carried out by reviewing and examining laws that are in accordance with legal issues (Ibrahim, 2010) The statutory approach is carried out by reviewing statutory regulations, especially regulations related to legal issues regarding legal protection for consumers in obtaining the clean water services for PDAM, it is Law Number 8 of 1999 concerning Consumer Protection.

\section{Legal Materials}

The legal materials in this research are primary and secondary legal materials. The procedure for collecting and processing legal materials to obtain reliable objective data is carried out library research, those are by comparing existing legal materials, statutory regulations, and expert doctrine, as well as other legal materials related to the problem being studied from the these materials, both primary and secondary legal materials (Fajar, 2010). The explanation of the legal material is as follows:

Primary legal materials are legal materials that have binding legal force in form of statutory regulations. The primary legal materials used in this research consist of:

1) Provisions regarding the duties and authorities of Regional Government in the Law of Republic Indonesia Number 9 of 2015 concerning Regional Government.

2) Provisions regarding legal protection for consumers in the Law of Republic Indonesia Number 8 of 1999 concerning Consumer Protection.

3) Provisions regarding the guarantee of the right to clean water for everyone in the Law on Water Resources Number 17 of 2019 concerning Water Resources.

4) Provisions regarding Regional Companies in Government Regulation Number 54 of 2017 concerning Regional Owned Enterprises. 
5) Provisions regarding the activities of the Regional Company for drinking water Surya Sembada, Surabaya City in the Regional Regulation of Surabaya city Number 2014 concerning Regional Drinking Water Companies.

6) Provisions regarding the management of water resources in the Decree of board Direction Number 349 of 2013 concerning the Regional Drinking Water Surya Sembada company, Surabaya City.

7) Provisions regarding the quality standard of clean water are in the Minister of Health Regulation Number 492 of 2010 concerning the quality requirements of clean water

Secondary Legal Materials, materials that are closely related to the primary legal materials. It consists of literature, books, legal articles / journals, online searches via the internet and other literature studies related to the issues being studied in this paper. Secondary legal materials used in this research are scientific journals, research results, and text books related to legal protection for consumers, as well as internet news related to the legal basis of consumer protection.

\section{Analysis of Legal Materials}

In this study the analysis of legal materials using prescriptive analysis. Prescriptive analysis is an argumentation that is carried out to provide an opinion or judgment regarding the right or wrong results of the research that has been done to answer this legal issue. This prescriptive analysis is used to provide a right or wrong assessment of the legal issue in this study, it is the legal protection of consumers for the clean water services of PDAM Surabaya City so that they are able to provide an assessment of Surabaya City PDAM business actors regarding the clean water services that they distribute to PDAM consumers according to consumer protection laws in Indonesia. The legal material collection techniques in this study are:

1. Legislation, in which this law is able to examine and find out about the meaning, regulation, and application related to legal issues.

2. Legal books and journals, where the books contain about historical, legal concepts and legal issues elaboration

3. Internet searches using websites, encyclopedias and legal dictionaries to support references and explain the definitions of word for word related to the legal issue. 
Some of these steps were collected in order to answer legal issues in the research questions (Marzuki, 2016). Those are regarding the legal protection of consumers for clean water services in PDAM Surabaya City.

\section{Results and Discussions}

\section{Quality Standards Of Water And Liability For Regional Companies In Surabaya} City

Business actors and consumers are two parties that are connected continuously and sustainably, it is none other than because they both need each other and are interdependent. The relationship between business actors and consumers is sustainable since the production process, distribution in marketing and offering. The series of activities are a series of legal actions and actions that have no legal consequences and which have legal consequences for all parties and only for certain parties.

In simple terms, it can be illustrated that there is a mutual relationship between PDAMs as service providers and consumers as service recipients. For example, the advantageous that PDAM gets as a business actor is the profit from consumer payments for services provided by PDAM. Meanwhile, the advantageous obtained by consumers are in form of fulfilling their daily needs for water services from PDAM.

The legal relationship between business actors and consumers originates from an agreement arising from the rights and obligations of the parties to carry out their respective achievements. The engagement that occurs between business actors and consumers arises from consent and/or law (Setiawan, 2010). Based on Article 1313 BW it is explained that "An engagement arising from an agreement is an act in which one or more people bind himself to one or more people". This agreement can be in written or unwritten form. An engagement that arises because of an agreement and it has been violated, after the fulfillment of certain conditions, become the cause default (wanprestatie). Default gives the party who suffers a loss the right to sue for compensation in the form of losses, fees and interest (Article 1236 of the Civil Code regarding the giving of something, Article 1239 of the Civil Code, and Article 1242 of the Civil Code to do or not do something, Articles 1243, 1244, 1246 of the Civil Code ) and others. Apart from costs that have actually been incurred, the losses are also 
included in the expected gain (winstderving) that was not received due to certain broken promises (Kristyanti, 2017).

While the alliance arising from the law is described in Article 1352 BW that "Alliances born of the law arising from the law as a result of the actions of the people", in other words for the emergence of the alliance is always required to have a legal statement (recht feit), so that Article 1353 of the Civil Code distinguishes alliances that arise from the law due to human actions according to the law and against the law. If a person is harmed by the actions of another, while there is no agreement between them (legal agreement), then based on the law can also arise or there is a legal relationship between that person and the person who caused the loss (Widjaja: 2001).

The parties involved in PDAM activities are business actors and consumers. The business actors are the service providers and the recipients are the consumers. Business actors and consumers are bound by an agreement, from which the agreement creates a legal relationship between the two. Among them are the rights and obligations of business actors that are reciprocated with the rights and obligations of consumers. In this case, business actors are obliged to fulfill the rights of consumers. Similarly, business actors are also entitled to receive what has become a consumer obligation. When compared to the general provisions in the Civil Code, it is clear that the regulations in the UUPK are more specific than the Civil Code. Because in UUPK business actors are not only being required to have good faith in running the business, but also must be able to create a sporty business without any cheating.

In a legal relationship, especially in the form of an agreement, that is, an agreement which has been agreed upon if it is violated by one of the parties, then the opponent can sue the party who hurting the appointments. If the consumer as a recipient feels that their rights are being violated by the business actors as service providers and previously there was an agreement agreed upon, then the consumer is able to sue the business actors on the basis of performance.

An agreement requires good faith from both parties to be able to fulfill its achievements responsibly. In this case, the law plays a very important role in ensuring the execution of an obligation with full responsibility in accordance with the original agreement.

As it has known, in obtaining water supply, consumers are bound by an agreement with the service provider, it is PDAM business actor. The article 1338 of 
the Civil Code states that "All agreements that are legally made are valid as laws for those who make them", so it is clear that the agreements made legally by the respective parties have binding legal force such as law. The point is, an agreement has the same legal force as a law so that the agreement is kept by the contract makers. The form of the agreement in this case is an agreement between consumers and PDAM Kota Surabaya and legal protection for consumers of PDAM Surabaya city.

It is possible that the agreement between consumers and PDAM Surabaya city is not implemented by one party or both parties, resulting in default. It is stated in Article 1234 of the Civil Code, "Default is a performance that is not carried out properly, so it is obliged to pay compensation that has been suffered" (Widjiastuti, 2013). The forms of default include:

a. Not doing what they were able to do

b. Do what was promised but not as promised

c. Doing what was promised but too late

d. Doing something that was not appropriate with the agreement (not contain in the appointments).

The Regulation of Surabaya Mayor number 29 Year 2011 Article 11 states that there is a legal relationship with consumers that is regulated in an agreement. The agreement includes the identity of the parties, the object of the agreement, fees, rights and obligations, prohibitions and sanctions.

The form of agreement between PDAM and PDAM consumers is proven by the presence of a customer ID that is obtained during registration. The agreement between the two occurs when they have officially become customers and have used the customer ID, where in the customer ID of course the identity of PDAM clean water service user is indicated. Since it is officially declared, there are obligations that must be fulfilled by business actors to consumers who have consumed clean water services that have been distributed by PDAM. Apart from the customer ID, there is a written agreement between PDAM and the consumer regarding the installation of a drinking water installation connection in which the form and content of the agreement is determined by PDAM. The consumers as client just need to sign the available form. This form of agreement can be called as a standard agreement which is based on the principle of contract freedom, which means that everyone can enter into any agreement as long as it is not prohibited by law, it does not conflict with morality and 
public order. The principle of contract freedom is reflected in article 1338 first paragraph of the Civil Code which states that all agreements made legally, as law that is valid for them who have made it.

Based on the news that has been read, PDAM Surya Sembada City is damaged and there is also a pipeline repair, so that the water is cut off for several days, while automatic water bill payments are still carried out on time, if the consumer makes a delay or forgets the payment, then will be cut off the flow of water will also be subject to fines. Due to the shutdown of water flow for several days, consumers feel that they are financially disadvantaged. In accordance with this, consumers are only charged with obligations, regardless of the rights that should be received properly.

In accordance with their position as a drinking water consumer who has entered into an agreement with the drinking water service provider, that is PDAM Surya Sembada, Surabaya City, one of the consumer's rights is the right to get safety in consuming the clean water that they receive. Based on the provisions of the 1999 UUPK, the rights to consumers are clearly stated in Article 4 letter (a) which reads, "The right to comfort, safety in consuming goods and / or services".

PDAM Surya Sembada Surabaya City as a business actor must be able to give the guarantee of quality of water that is being distributed. So that in getting the clean water flow has become a right for consumers. Apart from being clean, the right to safety for health and comfort in consuming water must always be fulfilled for the necessity of daily life. However, it is not enough for a consumer, if it is only entitled for safety water, every consumer also has other rights which can protect themselves from treatment or things that are detrimental to them.

It is undeniable that PDAM of Surabaya City as a business actor is not free from mistakes, but at least as a public service provider the PDAM is expected to be more care about the interests of consumers so that losses are not suffered by the consumer. It is the responsibility of PDAM in Surabaya City to think about the consumers' rights as recipients of its services, and it is also the responsibility to provide compensation in the event of damage, pollution, and consumer losses due to consuming traded things and services.

The obligation to maintain the quality of water supplied by PDAM can be given more attention. It has been confirmed in Article 8 UUPK 1999 concerning prohibitions for business actors, including: 
a. Does not meet or is not in accordance with the required standards and provisions of laws and regulations.

b. Not in accordance with the promise stated in the label, ticket, description, advertisement or sale promotion of the said things and /or services.

PDAM water must always maintain the quality, because it is also used as an ingredient for drinking water.

\section{The Quality Standards of water for Local Companies Drinking Water}

Kali Surabaya is part of Brantas Hilir River flow system. In addition, Kali Surabaya is used as a place for industrial waste water disposal and at the same time as water for industrial processes, which is located in Kali Surabaya watershed area. Kali Surabaya, especially in the downstream part, also has a function as drainage for settlements around the river, so that the denser population settlements in the watershed of river in Surabaya cause the level of river pollution by domestic wastewater are too increase.

Kali Surabaya currently serves as a source of raw water for East Java Province. Based on monitoring from the Environmental Agency (hereinafter referred to as BLH) of Surabaya City, $69.45 \%$ was lightly polluted, $22.22 \%$ moderately polluted and 8.33\% heavily polluted using BOD and TSS parameters, the concentrations had exceeded the standard class water quality standards. II. Under these circumstances, the water treatment costs will increase and the risk of decreasing the quality of treated water is increasing because it requires a large amount of chemicals for the processing. In addition, if the concentration of pollutant compounds in the raw water is very high, conventional processing with chemical precipitation will not be able to remove the existing compounds. (Yudo, 2019)

Based on the Regulation of the Health Minister of Republic Indonesia Number 492 of 2010 Article 3 states that "Drinking water that is consumed must be safe and also meets the microbiological, chemical and radioactive requirements contained in the mandatory parameters and additional parameters". From the research results, it is clear that the water quality standard in a number of Surabaya cities has reached $100 \mathrm{mg}$ for liter, so the water quality standard identified as cloudy or dirty is declared not meeting the requirements so that it is not suitable for consumption by consumers. 
Based on the news obtained, namely from the news that has been read, that there are not a few residents or consumers who have complained about the shutdown of PDAM water for days, clogged services, and it is u nclear when the water will flow, also related to the quality of water distributed to consumers' homes. Very cloudy or bad it can even be said to be unfit for daily use.

PDAM consumers who complain about the murky water also feel they are being harmed, because that is not suitable for use, especially for consumption. The murky water also cannot be used as drinking water, because it is feared that it can harm health, and as bath water, consumers are worried that it will make their skin rash. In this case there is a real loss suffered by consumers as recipients of PDAM Surabaya City water services.

According to the provisions of Article 4 UUPK states that, the consumer's rights are "The right to comfort and safety in consuming things and services", therefore, from these provisions it is the right of consumers to get clean, safe water for health, do not worry about consuming it, also feel comfortable to be able to fulfill life and daily needs (Miru, 2011)

As a clean water service provider company, PDAM Surya Sembada Surabaya City as a business actor is not only profit-oriented, but also oriented to the quality of quality water services. If it is related to the legal relationship between PDAM and consumers as customers, then with the quality standards that exist in the PDAM, it means that PDAM has committed default because the water provided or distributed to consumers is not appropriate or not in accordance with service standards as it should be, which can cause loss for consumers.

PDAM can be said to be in default if the consumer can show the Customer ID and also the agreement documents that are meant in the provisions of the Regulation of Surabaya Mayor. However, when the consumer is unable to show the evidence of the relevant agreement document, Thus, PDAM can be said to have committed an illegal act including violating the provisions contained in the UUPK, Surabaya Mayor Regulation and other regulations. Based on the turbidity of water in PDAM Surya Sembada, it can be said that, the condition of PDAM water is not in accordance with what is stated in the standard agreement from PDAM (attached), so it is more appropriate if PDAM has committed default, where the PDAM has violated the rights 
of consumers who should receive services water according to minimum service standards.

\section{Legal Remedies That is Able to be Taken By Consumers If Consumers Are Losing Clean Water Services By PDAM Surabaya}

The problems that are often complained by clean water consumers of PDAM Surya Sembada Surabaya City are traffic jams or no water flow for several days and also the water flow that is murky, dirty and the poor service from PDAM. Such service certainly makes PDAM water consumers feel disappointed, even though the consumers have carried out their obligations properly, it is by paying bills on time, because if it is late the consumers will receive consequences.

Legal efforts are needed to answer a problem that occurs between consumers and PDAM Surabaya City as business actors related to losses suffered by consumers. Based on the context of Civil Law, the compensation that must be made by the party causing the loss is a form of liability or compensation. The responsibility referred to is the business actor, which is obliged to pay compensation for what has been suffered by PDAM consumers and if the business actor breaks his promise, the consumer can sue the business actor in court or outside the court.

Based on the article 19 of UUPK states that, the responsibility of business actors to the consumers is regulated in Chapter VII Article 19 to article 28 of the UUPK. These responsibilities includes:

(1) Business actors are responsible for providing compensation for damage, pollution and / or other consumer losses resulting from consuming things and / or services produced or traded by the business actor;

(2) The compensation as referred to in paragraph (1) It can be in the form of a refund or replacement of things and / or services of a similar or equivalent value, or related to health care and / or provision of compensation in accordance with the provisions of laws and regulations applicable;

(3) The compensation is granted within a grace period of 7 (seven) days after the transaction date;

(4) Providing compensation as referred to in paragraph (1) and paragraph (2) does not eliminate the possibility of a criminal charge based on further evidence regarding the existence of an element of error; 
(5) The provisions as referred to in paragraph (1) and paragraph (2) shall not apply if the business actor can prove that said mistake is the fault of the consumer.

Responsibility is carried out as a manifestation of awareness of their obligations in bearing a consequence of actions that have been carried out by PDAM business actors.

In connection with the existence of UUPK Number 8 of 1999, legal remedies that can be taken for every consumer who feels aggrieved, it is by suing business actors through institutions that are tasked with resolving problems between consumers and business actors, either through the judiciary or outside the court, it is by involving the parties concerned.

According to UUPK Article 45 paragraph (2), legal remedies carried out in Indonesia generally be resolved or taken in 2 (two) ways, it is through solving problems outside the court (non-litigation) and solving problems through court processes (litigation). In the provisions of the UUPK it has been explained that a lawsuit through a court is a form of efforts to resolve consumer problems carried out if the non-litigation settlement process does not achieve a result. The following is the problem solving process;

1. Non Litigation (Out of Court)

a. Settlement of consumer problems peacefully by consumers with PDAM Surya Sembada Surabaya City.

The purpose of holding the problem settlement outside the court is to reach an agreement regarding the amount of compensation or an action as a guarantee not to repeat it for what was suffered by the party who suffered the loss.

Article 23 UUPK states that, "Business actors who refuse and / or do not fulfill consumer compensation claims as in Article 19 paragraph (1), paragraph (2), paragraph (3), and paragraph (4), can be sued through the consumer dispute resolution ".

Settlement of problems between business actors and consumers allows for a peaceful settlement, that is, without having to go through court as long as it does not conflict with the law. In Article 45 paragraph (2) it is stated that the UUPK requires peaceful settlement by both parties to the dispute, and is a legal remedy that must take precedence before the parties choose another Judicial Body to resolve the dispute. 
b. Resolution of consumer problems through the Consumer Dispute Resolution Agency (BPSK)

The government has formed an agency to resolve consumer problems outside the court, namely the Consumer Dispute Resolution Agency (BPSK). By this BPSK, the settlement of consumer problems outside the court can be carried out quickly and easily. It is said to be fast because the law has issued a provision that BPSK must give a decision no later than 21 working days after the lawsuit is received.

For the consumers whose rights have been harmed by business actors, they can complain to the BPSK institution, complaints can be made directly or can be represented by their legal counsel. The complaint can be reported in writing or not in writing to the nearest BPSK Secretariat at the place where the consumer lives (Nasution, 2011)

The settlement of consumer problems outside the court held at BPSK is nothing but to pay and guarantee the amount of compensation suffered (Tobing, 2015) The size of the amount of compensation suffered by consumers is based on the result of using the things and services traded by the business actor. Meanwhile, the form of guarantee referred to is the existence of a written statement from the business actor stating that the business actor will not repeat actions that may cause consumer losses.

In addition, based on the Regulation of the Mayor of Surabaya Article 38 Number 29 of 2011 states that:

1. The community (PDAM customers) and related parties can play a role in:

a. Providing information about the interruption of PDAM services;

b. Provides protection for raw water.

2. The community and related parties have a right to provide oral or written advice in order to improve PDAM services.

3. To fulfill the community's rights as referred to in paragraph 2, PDAM can provide adequate facilities.

4. Further provisions related to procedures and implementation as well as the role of the community and related parties are regulated by PDAM regulations.

\section{Litigation (Court)}

Between parties do not want to implement a peaceful path, between parties can resolve problems through the court according to Article 46 of the UUPK, namely by: 
a. Civil consumer dispute resolution

b. Criminal or public consumer dispute resolution

c. Settlement of consumer disputes through HTN or material test rights

Of the three forms of dispute resolution above, filing a civil suit is settled according to civil law and at the General Court.

Settlement of problems by consumers conducted through court channels is the last means of obtaining compensation for mistakes made by business actors. Business actors should have an obligation to consumers for things and services that have been consumed in a proper condition. If the business actor has been negligent in maintaining the quality of the water it produces and has been distributed by PDAM consumers, the business actor is deemed to have defaulted on the consumer which could result in consumer loss of the things for services it consumes. It is regulated in Article 1243 of the Civil Code which states that, "Reimbursement of costs, losses and interest due to the fulfillment of an agreement is mandatory, if the debtor, even though it has been declared negligent, remains negligent to fulfill the agreement, or if something that must be given or done can only be given or done in a time that exceeds the appointed time ".

Consumers who are harmed by business actors are able to propose a lawsuit through the general court. (Endripraja, 2016). In accordance with Article 48 UUPK, that "The settlement of consumer disputes through the court refers to the provisions of the general court that apply". Thus, consumers can file claims for compensation rights just like filing an ordinary civil lawsuit, it is based on the result of default due to mistakes by business actors which cause harm to consumers. According to Article 23 of the UUPK, civil lawsuits proposed by consumers against business actors through district courts can be filed at the district court where the consumer is the plaintiff.

So, the legal remedies that can be carried out by the consumers of clean water whose rights have been harmed by Surabaya City PDAM Surya Sembada, especially regarding the flow of water that comes out is very cloudy, is to report directly to PDAM Surya Sembada or can submit a lawsuit through a consumer protection agency. This is of course in accordance with Article 45 paragraph (2) of the UUPK, which reads "Settlement of consumer disputes can be pursued through the court or outside the court based on the voluntary choice of the disputing parties". It has also been regulated in Article 46 paragraph (1) of the Company Law, which states that "A 
lawsuit against a business actor's violation can be made by an injured consumer, a group of consumers who have the same interests or a consumer protection agency".

Furthermore, it is known that the existence of a legal relationship between business actors and consumers, as a consequence if the business actor has committed a violation that makes the consumer feel disadvantaged, the consumer has the right to sue the business actor so that they can claim compensation for what they suffered. In this case the regulation is clear, that is as stated in Article 19 UUPK states "business actors are responsible for providing compensation for damage, contamination, and consumer losses due to consuming things and services are produced or traded".

In line with this, PDAM Surya Sembada Surabaya City, with the discovery of a product in form of turbid or dirty water that is channeled to PDAM consumers, can provide relief from reducing monthly fees or fees for PDAM account payments. However, until now there has never been a replacement.

\section{Conclusion}

From the results related to the research question, it can be concluded that:

1. The water quality standard of PDAM Surya Sembada Surabaya City which is identified as murky or dirty can be stated that the PDAM has committed default, due to it is in accordance with what has been stated in the standard agreement (attached) of PDAM itself.

2. Legal remedies that can be taken by the consumers are being able to propose claims for compensation for the things or services they consume in 2 (two) ways, those are that they can be done outside of the court (non-litigation) and throughout the court process (litigation).

\section{REFERENCES}

Amiruddin \& Asikin, Z. (2012). Pengantar Metode Penelitian. Rajawali Pers. Endipradja, F. T. (2016). Humum Perlindungan Konsumen:Filosofi Perlindungan Konsumen Dalam Prespektif Politik Hukum Negara Kesejahteraan, Setara press.

Ibrahim, J. (2010). Teori \& Metodologi Penelitian Hukum Normatif. Banyumedia. 
Kumalasari, F. \& Satoti, Y. (2011) Teknik Praktis Pengolahan Air Kotor Menjadi Air Bersih Hingga Layak Diminum. Laskar Aksara.

Kristiyanti, C. T. R. (2017). Hukum Perlindungan Konsumen. Sinar Grafika.

Marzuki, P.M. (2016). Penelitian Hukum. Kencana Prenada Media Group.

Miru, A. \& Sutarman, Y. (2011). Hukum Perlindungan Konsumen. Rajawali Pers.

Fajar, M. (2010). Dualisme Penelitian Hukum Normatif dan Empiris. Pustaka Pelajar.

Nasution, A.Z. (2001). Hukum Perlindungan Konsumen Suatu Pengantar. Diadit Media.

Satmoko, Y. (2019). Kondisi Kualitas Air Sungai Surabaya (Studi Kasus : Peningkatan Kualitas Air Baku PDAM Surabaya), Jurnal Teknologi Lingkungan, 20 (1), p. 20. http://epaper.bppt.go.id/index.php/ITL/article/view/2547

Setiawan, R. (1978) Pokok - Pokok Hukum Perikatan, Bandung : Bina Cipta.

Tobing, R. D. (2015) Aspek-Aspek Hukum Bisnis (Pengertian, Asas, Teori dan Praktik). LaksBang Justitia.

Widjaja, G. \& Yani, A. (2001) Hukum Tentang Perlindungan Konsumen. Gramedia Pustaka Utama.

Widjiastuti, A. (2013). Hukum Perlindungan Konsumen yang Berfungsi Sebagai Penyeimbang Kedudukan Konsumen dan Pelaku Usaha dalam Melindungi Kepentingan Bersama. Jurnal Gema Aktualita, 2 http://dspace.uphsurabaya.ac.id:8080/xmlui/handle/123456789/71 